\title{
DEVELOPMENT OF THE PARTS OF SPEECH THEORY IN RUSSIAN RUSISTICS
}

ABSTRACT

\author{
A.K. KARPOV \\ Nizhnevartovsk State University \\ president@nvsu.ru \\ L.N. ROTOVA \\ Nizhnevartovsk State University \\ fil@nvsu.ru \\ M. RUIZ-ZORRILLA \\ University of Barcelona \\ m.ruizzorilla@ub.edu
}

This paper analyzes the development of parts of speech theory in Russian rusistics within the period of the past two hundred years. The analysis allows us to consider the approaches towards the classifications based on various principles (logic, psychological, positivistic, functional, cognitive) and come up with the characteristics enabling the scholars to give noncontradictory linguistic definitions to the parts of speech, state their exact number, identify the boundaries between them and develop a system of parts of speech.

KEYWORDS: part of speech, structural and semantic classification, homogeneous classification, heterogeneous classification, transitivity of parts of speech, syncretic words, primary and secondary parts of speech.

\section{INTRODUCTION}

The problem of parts of speech has been a subject of a scientific research for a long time. Numerous scholars are trying to define the essence of parts of speech and work out an optimal approach to their differentiation. Russian science is no exception in this respect. Starting with M.V. Lomonosov, almost every prominent Russian linguist had put forward his or her own idea of the parts of speech and come up with own criteria of distinguishing between them. The efforts were considerably successful, yet linguists still face the language realia that do not fit the existing theories. Such facts urge scholars to search for new paradigms within a number of disciplines in some ways related to linguistics, such as cognitive science, rather than linguistics proper.

The fact that it is impossible to come up with a non-contradictory definition of the parts of speech has become a stumbling block for theoretical grammar. If such a definition were formulated, the problems of the number of parts of speech in a certain language, their definitions, and hence the problem of borderlines between word classes, would stand no longer. However, a linear solution to the above mentioned complex of problems is apparently impossible, due to stochastic nature of the language (14), and modern science is only able to explain why things are this way and not otherwise. 
The history of parts of speech study in the Russian language may be roughly subdivided into three periods.

The first period (late $18^{\text {th }}$ - early $19^{\text {th }}$ centuries) is related to the works by M.V. Lomonosov, N.I. Gretsch, A.Ch. Vostokov, V.G. Belinsky, G. Pavsky, I.I. Davidov, F.I. Buslaev, K.S. Aksakov and others.

The second period (late $19^{\text {th }}$ - early $20^{\text {th }}$ centuries) is the period of works by A.A. Potebnya, D.N. Ovsyaniko-Kulikovsky, I.A. Baudouin de Courtenay, V.A. Bogoroditsky, F.F. Fortunatov, A.A. Shakhmatov, A.M. Peshkovsky, M.N. Peterson, D.N. Ushakov, L.V. Shcherba, etc.

The third period (the second half of the $20^{\text {th }}$ century - up to the present time) is connected with the works by V.V. Vinogradov, G.O. Vinokur, A.A. Reformatsky, V.N. Sidorov, I.I. Meshchaninov, L.A. Bulakhovsky, A.N. Gvozdev, N.S. Pospelov, M.V. Panov, S. Kuznetsov, A.A. Zaliznyak, E.S. Kubryakova, A.E. Suprun, N.U. Shvedova, A.V. Bondarko and others.

\section{PARTS OF SPEECH - LOGICAL AND SEMANTIC WORD GROUPING}

During the first period the linguists understood parts of speech as logicogrammatical (logico-semantic) groups of words. Following Greek and Roman grammars, M.V. Lomonosov claimed that parts of speech are correlated with logical categories of thought.

The word (speech - A. Karpov) is given to people in order to communicate their concepts to others. And so they understand the concepts of things and their actions and communicate to others. Verbal images of things are called nouns, e.g.: небо, вътрть, очи; images of actions are verbs, e.g.: синғетъ, ветьть, видятъ. Since they denote things or actions, they by right may be called notional parts of word $(25, \S 40)$.

Proceeding from their functions in speech, M.V. Lomonosov singled out eight "notional parts":

Thus a human word has eight notional parts: 1 ) a noun to name things; 2) a pronoun for short naming: 3) a verb to name actions; 4) a participle to combine a noun and a verb into one unit for shortness; 5) an adverb to briefly describe the circumstances; 6) a preposition to show the relation of circumstances to things and actions; 7) a conjunction to show reciprocity of our notions; 8) an interjection to briefly express the emotional impulse. $(25, \S 46)$

M.V. Lomonosov divided the notional parts of speech into principal and functional, with a noun and verb recognized as principle, for they are "parts of a human word, necessary to describe our most important concepts" (25, § 45).

As follows from the above, neither morphological nor syntactic criteria are taken into account when differentiating between parts of speech, whereas obvious preference is given to grammatical semantics. For a long time semantic 
criterion was the main and underlying one in the history of parts of speech study, even though morphological markedness of a word, which in most cases directly indicates its part of speech nature, is typical of the Russian language.

M.V. Lomonosov's grammatical views were maintained by A.Ch. Vostokov, N.I. Gretsch, F.I. Buslaev, G. Pavsky and other Russian scholars, who worked in the period of comparative-historical linguistics booming development, when historical grammar of the Russian language was born.

\section{PARTS OF SPEECH - PSYCHOLOGICAL OR FORMAL GRAMMATICAL WORD GROUPING}

The second period is related to the works by two Russian research schools of the parts of speech study, such as psychological and formal grammatical schools. The first school, represented by A.A. Potebnya, D.N. OvsyanikoKulikovsky and other scholars, treated a part of speech primarily as a psychological reality, as a category of human mind. According to A.A. Potebnya, lexical and formal word meanings make up one act of thought. As seen by the scholars, the language would go from words to thoughts. A thought is formed in a sentence, and a word is a part of a sentence, therefore the study of parts of speechs only possible when based on a sentence. Thereby, A.A. Potebnya suggested using two characteristics - grammar-semantic and syntactic - to study a word from the parts of speech point (17).

The Russian psychological school of the 1850-s was to a certain extent influenced by W.von Humboldt's philosophy of language and H. Steinthal's comparative-historical linguistics, being a reaction to excessive spread of logical views on the nature of language. A.A. Potebnya's followers were seeking to empirically describe the essence of perception, impressions, memory, knowledge and other psychological processes and only then, on that background, reflect a part of speech.

Thus, D.N. Ovsyaniko-Kulikovsky in his work "The Russian Language Syntax" described the adjective in the following way: "We distinguish things (objects and creatures) on the one hand, and properties, qualities of these things on the other hand. These properties or qualities are nothing but impressions of things we get through our sense organs (eyes, ears, etc.) ... Our ability to ascribe qualities to things according to our impressions helps us distinguish between things, get our bearings in the surrounding world and learn it. It is the beginning and source of any knowledge. Such ability is called the ability to objectify impressions. An object means a thing of the outer world; therefore to objectify an impression means to turn it into something outer, something around us. We will call any objectified impression, i.e. ascribed to an object as its property, its quality, its attribute" $(15,36-37)$. 
In the final analysis, the definition of an adjective has a descriptive character and is based only on the semantic feature, "it is a part of speech or a form of thought, conveying characteristics which passively exist in the objects" (15, 37-38).

Being engaged in scientific and teaching work in Moscow University in 1876-1902, F.F. Fortunatov founded a research school later called Moscow (Formal) Linguistic School. He tried to overcome mixing of grammar with psychology and logics, thus predetermining the search for better ways and methods of linguistic analysis. The oppositions between "word change" and "form change" as well as "syntactic" and "non-syntactic" grammatical categories (later used in other works), popular in Russian grammatical tradition, go back to the works by F.F. Fortunatov (30). He suggested to classify parts of speech basing on consecutive application of morphological principle and introduced the term "formal classes" for word classes (parts of speech) (10, 578).

F.F. Fortunatov's pupils included A.A. Shakhmatov, M.M. Pokrovsky, D. N. Ushakov, N.N. Durnovo, A.M. Peshkovsky, V.K. Porzhezinsky, V.M. Istrin, V.N. Shchepkin, B.M. Lyapunov, A.M. Tomson, S.M. Kulbakin, and a number of foreign scholars. His school is also referred to as the Moscow Fortunatov School.

Elaborating on the ideas of the morphological school of Academician F.F. Fortunatov, M.N. Peterson suggests to classify words basing on differentiation of word-changing forms. The classification includes two groups: words which change forms and words which do not change forms. The first group comprises case words (having case forms), gender words (having gender forms), personal words (having forms of person). Gender words fall into two groups: a) words having only gender forms (xopou $-a,-o$ ); b) words having gender and case forms (хорошиц, - $а я,-е e)$. The first group can be exemplified by words like добp (in traditional classification - a short adjective), ходил (a verb in past tense), брошен (a short form of Past participle), the second group includes words like xрабрый (a full form of an adjective), бегающцй (Present participle), первыц (an ordinal numeral), эmom (a pronoun).

Thereby, according to M.N. Peterson, the words traditionally classified as adjectives belong to the class of gender words conveying the meaning of quality inherent in an object. The form of gender in these words "means that they refer to a case word of a certain gender: человек добр, а мать добра, платье хорошо оr добрый друг, молодая сестра, злое дитя» $(16,39)$.

Not all the words with a gender category should be referred to gender

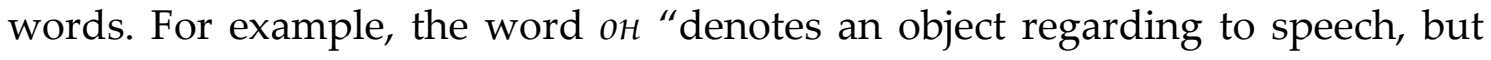
only an object of a masculine gender, она - feminine gender, оно - neuter gender, their gender does not depend on the gender of the words they collocate with. On the other hand, бexulu, for example, does not mean that the quality denoted by this word is of a masculine gender, it shows that the word in this 
form is collocated with the masculine word, e.g., бельй снег. Thereby, the words он, она, оно should be referred to case words" $(16,40)$.

As for gender words, both number and case forms have a meaning different from case words. Number and case forms of gender words denote that these words refer to case words in a respective case form of singular or plural number, whereas in case words the number denotes singularity or plurality, with the case conveying one or another case meaning.

The classification based on formal indicators and relying on ample language data had an undoubtedly great scientific value. However, due to its irregularity, original nature and drastic deviation from traditional logicosemantic parts of speech classification, it required further elaboration and reconsideration. Nevertheless, the scholars came with nearly the most important principle for the parts of speech system of the Russian language - the morphological principle.

Further works by F.F. Fortunatov's followers led to new significant principles and development of a complex approach to the parts of speech characterization, which meant a gradual shift from homogeneous (based on one characteristic) to heterogeneous (multi-characteristic) approach.

An important advance was made by A.A. Shakhmatov, who turned the syntactic principle, when a word as a part of speech is defined by its relation to the sentence and speech in general, into the basic principle for classifying parts of speech. Generally, parts of speech differ in terms of their morphological features. However, this often is not enough, as it's essential to consider the semantic and syntactic properties of each part of speech. Hence, a part of speech is a group of words formed by "the relations of basic word meanings to concomitant grammatical notions" $(1,15)$. The basic meanings of words convey the notions of substances (дом, сестра, поле), properties and qualities (красивый, деревянныи), actions and states (бежать, любить), relations (стол и стул). Grammatical notions accompany basic meanings and manifest themselves in a grammatical form through morphological and syntactical means, e.g. in the word combination красивыи человек the adjective красивый collocated with the noun человек acquires a form of masculine gender, singular number, nominative case which are in grammatical agreement with the noun. Thus, A.A. Shakhmatov clarified three basic principles of parts of speech division for the Russian language, such as semantic, morphological and syntactic principles. A.A. Shakhmatov was the first define a part of speech based on these principles.

Another F.F. Fortunatov's pupil and follower, A.M. Peshkovsky, suggested a new lexico-grammatical principle of differentiating between parts of speech. "A.M. Peshkovsky thought of his syntax theory as a synthesis of A.A. Potebnya's ideas focusing on the semantic aspect of language phenomena and F.F. Fortunatov's theory focusing on formal language means" (24, VI). "To understand the exceptional importance of A.M. Peshkovsky's advance, it's worthwhile to remember two extreme approaches characterizing the linguistic 
descriptions during that time. The first extreme approach is semantic radicalism, which you can see when you compare, for instance, the definition of a noun as a part of speech with the meaning of thingness, of a verb as a part of speech with the meaning of action, of a sentence as a group of words expressing a completed thought, and so on, regardless the morphological, syntactic and other formal properties of the respective objects. The second extreme approach is formal radicalism, which prevented from considering, for example, the wordform жене as two different grammatical forms of the noun жена (dative and prepositional cases), as this kind of difference was not marked on the level of the denoting word" (24, VI). A.M. Peshkovsky managed to reduce that radical approach by showing that the meaning of a word and a form of this word, including intonation, constitute a unity, which allows to view this word as a part of speech. The conception worked out by A.M. Peshkovsky has not been fully accepted, though.

The idea to classify parts of speech taking into consideration both formal and semantic aspects of a word was fully elaborated by L.V. Shcherba. He suggested grouping words basing on the morphological, syntactic and semantic principles altogether. According to L.V. Shcherba who paid primary attention to the semantic principle, the classification of parts of speech is based on the categories of thingness, action and property common to all languages (23).

In the end of the second period in the part-of-speech theory development the scholars came to the conclusion that parts of speech may be differentiated judging from essential semantic, morphological and syntactic principles. Linguists did not seek for an exhaustive definition of the "part of speech" notion, using empirical descriptions for the most part, for example: "Major grammatical classes of words are so-called parts of speech, i.e. grammatical classes, including words which make up sentences as the main speech units and fulfill certain grammatical functions. However, not all words of the Russian language may be called parts of speech. For example, some word classes, such as words expressing affirmation and negation ( $\partial a$ and $\mathrm{Hem})$, exclamatory words called interjections (oй, ax, yвъ, etc.), parenthetical words (дескать, мол, значит, конечно, следовательно, еtс.) and some others do not function as members of a sentence and consequently they are specific word classes rather than parts of speech" $(1,83)$.

Another Russian linguist, V.V. Vinogradov, made an analysis of the works by different scholars in terms of the number of parts of speech studied.

Traditional Russian grammar developed under the impact of Antique and West European grammar theories, singled out eight parts of speech, then nine parts of speech, whereas now - including particles - the number of parts of speech comes up to ten: [...] Moreover, sometimes participles and adverbial participles are either referred to verb forms, or to mixed, transitional parts of speech, or considered to be specific parts of speech (in which case the number of parts of speech comes up to twelve). $(4,38)$. 
The number of parts of speech in the works of different scholars ranges from two to twelve $(4,38-40)$.

\title{
4. PARTS OF SPEECH - STRUCTURAL AND SEMANTIC WORD GROUPING
}

The beginning of the third period in the development of parts-of-speech theory falls on the middle of the $20^{\text {th }}$ century. In 1947, V.V. Vinogradov published his book The Russian Language (Grammatical Theory of Words), where he characterized the system of parts of speech and particles of speech and wrote,

\begin{abstract}
General structural-semantic types of words in the Russian language most definitely reveal grammatical differences between different categories of words in the system of parts of speech. The way parts of speech are classified into the basic grammatical categories is conditioned by: 1) the differences between the syntactic functions, performed by different categories of words in connected speech and in the sentence; 2) the differences between the morphological system of words and word-forms; 3) the differences between the lexical meanings of words; 4 ) the differences between the ways of reflecting reality; 5) the differences between the nature of correlative and collaterally subordinated grammatical categories which are connected with one or another part of speech $(4,38)$.
\end{abstract}

It was the first comprehensive definition of the "parts of speech" in Russian Rusistics, aimed at developing a whole system where general definition allowed deriving special ones which revealed both integral and differential features of parts of speech. Developing the notion of "parts of speech", V.V. Vinogradov focuses on the three main characteristics of parts of speech, such as grammatical semantics, and morphological and syntactical features.

The classification of parts of speech introduced by V.V. Vinogradov's has a structural and semantic nature based on lexico-grammatical differentiation of parts of speech. His system includes four categories of words: 1) parts of speech; 2) modal words; 3) particles of speech; 4) interjections. The "parts-ofspeech" category includes names (nouns, adjectives, numerals), remains of pronouns, verbs, adverbs, and statives. The "particles-of-speech" category includes particles, link-words, conjunctions, and prepositions.

It took some time for V.V. Vinogradov's innovative ideas to go beyond academic community. In the early 1950-ies, the scholars were required to develop a well-thought and traditional grammar of the Russian language, which could fully meet the needs of public education, hence Russian Grammar was written in 1952-1954, followed by an almost unaltered second edition in 1960.

The book contains no rigorous definition, but rather a more or less detailed description of parts of speech. 
The Russian words are divided into classes different in their main meanings, in the nature of grammatical categories related to each of these classes, as well as in types of word-formation and form-change. These classes are called parts of speech. Parts of speech also differ in functions they perform in connected speech. (5: 19)

Proceeding from this definition, we may conclude that parts of speech are singled out judging from four essential features: semantic, morphological, syntactic and word-building ones. The latter feature was brought in considering the theory of word-formation rapidly developing at that time. Each description of the notional part of speech in Russian Grammar 1960 was accompanied with an ample characteristic of word-formation peculiarities.

As for the number of parts of speech, 1960's Russian Grammar states the following,

Traditional Russian grammar used to distinguish between nine parts of speech, such as a noun, an adjective, a numeral, a pronoun, a verb, an adverb, a preposition, a conjunction and an interjection. Presently, a tenth part of speech, a particle, has been added. $(5,19)$.

Russian Grammar still serves as a basis for school grammar textbooks and various guidance materials, for it is directly connected with Russian orthography and punctuation, with the established norms of pronunciation, reading and writing.

In the period between 1960 and 1970 Russian language studies came out to the front line of the world linguistics, with conditions for a fundamentally new academic grammar, which could summarize the most essential scientific achievements in all areas of Russian Rusistics.

The short Grammar of Modern Russian Literary Language published in 1970 and preceding a new academic grammar contains clear definitions of the parts of speech, which can no longer be considered empirical descriptions, but rather strict and generally accepted scientific terms.

Parts of speech are word classes characterized by: 1) same categorial meaning, i.e. the meaning abstracted from lexical meaning of all the words of a given class and from grammatical categories proper to this class; 2) general paradigmatics; 3) identical syntactic functions $(6,304)$.

This grammar theory states three significant features of the parts of speech (semantic, morphological and syntactic) and defines ten parts of speech, "All the words of the modern Russian language are divided into 10 parts of speech, such as 1) a noun; 2) a pronoun-noun; 3) an adjective; 4) a numeral; 5) an adverb; 6) a verb; 7) a preposition; 8) a conjunction; 9) particles; 10) an interjection" $(6,304)$. Pronoun-nouns are singled out into a separate class, whereas other pronouns are grouped either with adjectives or with adverbs. Russian Grammar of 1970 is adherent to the morphological principle, which is fully in compliance with the structural ideas of that time. 
The definition of the parts of speech given in Russian Grammar (1980) is meant for morphology experts. It is rather academic, filled with scientific terms and requires a reader to have a deep knowledge of the matter,

Parts of speech are grammatical classes of words, characterized by a set of the following features: 1) generalized meaning, abstracted from lexical and morphological meanings of all the words of the given class; 2) a set of specific morphological categories; 3 ) a general (identical) system of paradigms; and 4) the same main grammatical functions (18: 457).

As for the identification of parts of speech, Russian Grammar of 1980 does not differ from Russian Grammar of 1970.

Concise Russian Grammar (1989) was based on the Russian Grammar (1980), but the definition of the parts of speech differs in a way from the original one:

Parts of speech are the biggest grammatical word classes, characterized by the following three features: 1) generalized grammatical meaning, abstracted from lexical meanings of words and from categorial morphological meanings; 2) a specific set of morphological categories and the same paradigm; 3$)$ the same main syntactic functions. $(7, \S 12)$

The division of words into ten parts of speech is traditional. All parts of speech are subdivided into notional and functional. Nouns, adjectives, numerals, pronoun-nouns, adverbs and verbs belong to notional parts of speech; prepositions, conjunctions and particles belong to functional parts of speech. The tenth part of speech, interjection, belongs neither to notional nor to functional words: interjections do not designate anything, they express emotional reactions to facts of reality. $(7, \S 12)$

Thus, Russian Grammars of 1970, 1980 and 1989 reflect the same point of view on the number of parts of speech in the Russian language, despite some differences in defining the main notion. Reference books and encyclopedias of the modern Russian language, basing on academic grammars, provide simpler and more understandable definitions, which nevertheless fully convey the notion of parts of speech:

Parts of speech are word classes singled out due to the same syntactic, morphological and semantic properties. (10: 578$)$.

Parts of speech are word classes characterized by the same generalized meaning (e.g., thingness in nouns, process in verbs), abstracted from lexical meanings of all the words of the given class; by the same grammatical categories and word inflections; by common syntactic functions. (19: 618).

It is significant that the definitions comprise three main features of parts of speech - semantic, morphological and syntactic. 


\section{MODERN APPROACHES TO CLASSIFYING PARTS OF SPEECH}

The question of parts of speech, their number and volume and differentiation principles has not been completely solved. Modern rusistics scholars continue to search for solutions develop new theories and classification methods based on V.V. Vinogradov's theory $(20,17)$. Heterogeneous classification is one of the methods to differentiate parts of speech. It is a step-by-step procedure of dividing words into groups according to the established criteria. The criteria to group words into parts of speech are as follows: 1) notional - non-notional nature of words; 2) the word's manner of reflecting reality; 3) categorial meaning of a word; 4) morphological features of a word; 5) syntactic features of a word; 6) word-building features of a word. All these criteria have been familiar for quite a while, going back to the works by V.V. Vinogradov and his predecessors, but the first and the fifth criteria were usually treated as optional. Structural-semantic classification of the parts of speech based on three main features is used in school, where students carry out a step-by-step morphological analysis of a word-form derived from a particular context.

The term "heterogeneous", borrowed from natural sciences, is used in linguistics in such combinations as "heterogeneous classification" (mentioned above) and "heterogeneous parts of speech" (28), where the former can be substituted by the word "structural-semantic" and the latter - by "nonuniform".

From the very first attempts to describe parts of speech, almost every scholar and researcher had to face the phenomenon of "heterogeneity". Some scholars analyzed the transitivity between the parts of speech $(4 ; 13)$ and syncretism zones in the system of parts of speech in the modern Russian language (2), etc. E.I. Dibrova's guidance on the modern Russian language grammar gives a detailed interpretation of this phenomenon explained by the transition of one part of speech into another a) by means of change (often repeated) of a morphological and word-building-morphological indicator: зеленый-зелень-зеленеть-зелено; дерево-деревянный-деревенеть-деревянно; бегать-бег-бегльий-бегло, еtс.; б) by transition of one part of speech into another: книга-книжный, бумага-бумажный, ручка-ручной, телефон-телефонный, яблоко-яблочный, хлеб-хлебный, etc. "The transitivity results in syncretism. Syncretic words combine the features of two or more parts of speech in their grammatical structure (categorial meaning, morphological and syntactic properties)" $(4 ; 13 ; 2 ; 20)$. Syncretic words are also called hybrid or intermediate words or contaminants $(4 ; 2)$. They form syncretic parts of speech.

All notional parts of speech are divided into two groups - non-syncretic (primary) and syncretic (derived). The correlation between these parts of speech is reflected in the following table, where the upper line shows primary parts of speech and the lower line shows the derived parts of speech. 


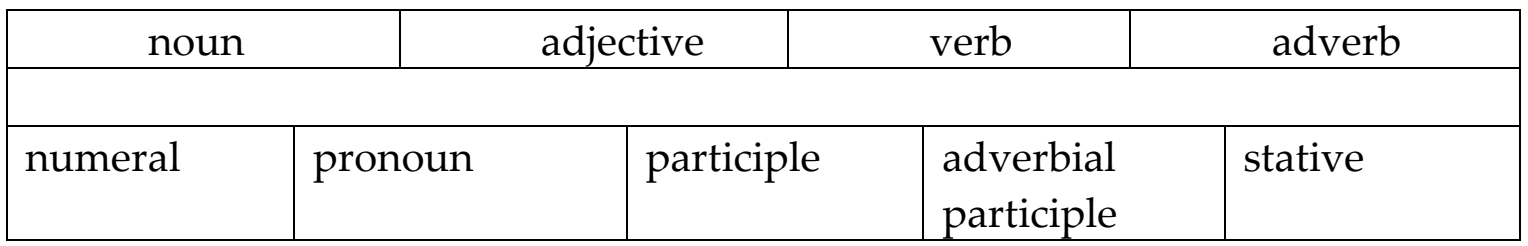

Speaking about the derived parts of speech, scholars consider synchronic rather than genetic ties, which allow making conclusions about the availability of a certain syncretic property in a group of words $(20,26)$.

The problem of detecting and describing transitivity among parts of speech is one of the most significant achievements of modern parts-of-speech study. Dividing the parts of speech into primary and derived ones makes scholars reconsider many aspects of morphology teaching. Besides, linguistic conclusions on the parts-of-speech system go well together with the data of cognitive science.

\section{CONCLUSION}

Thus, by analyzing the development of the parts-of-speech theory, we concluded the following: a) scholars tried to consider the question from a definite point of view -logical and philosophical (antique tradition), logical, psychological, positivistic, functional, and cognitive; b) find essential features enabling to give non-contradictory definitions of parts of speech, state their number, draw borderlines between them, and make a system of defined parts of speech.

During the first period, the parts-of-speech theory was dominated by the logical and semantic principle. The traditional system of parts of speech gradually took shape and was applicable in terms of teaching grammar. The second period resulted in the development of structural and semantic system of parts of speech based on the combination of semantic, morphological and syntactic features. The drawback of that system is in the fact that only "pure", ideal representatives of a certain part of speech have all three features, while other examples may fall out of the definition and may be shifted from one part of speech to another (e.g. ordinal adjectives/numerals).

In the second half of the $20^{\text {th }}$ century, due to the intensive study of wordbuilding, scholars paid special attention to transitivity in the parts-of-speech system and such phenomena as "substantivization", "adjectivization", "pronomenalization", "adverbalization" (noted by A.A. Shakhmatov), and other suchlike processes and numerous hybrid words. Transformology as a branch of linguistics dealing with transitivity processes allowed for dividing notional words into primary and derived, which undoubtedly has broken new ground in parts of speech morphology. 


\section{BIBLIOGRAPHY}

AVANESOV, R.I., SIDOROV, V.N. (1945), Ocherk grammatiki russkogo literaturnogo yazyka. Chast 1. Fonetika $i$ morfologiya [Outline of grammar of the literary Russian language. Part 1. Phonetics and morphology]. Moscow, Gosudarstvennoe uchebno-pedagogicheskoe izdatelstvo Narkomprosa RSFSR.

BABAJTSEVA, V.V. (1983), Zona sinkretizma $v$ sisteme chastey rechi sovremennogo russkogo yazyka [Syncretic zone in the parts of speech system of the modern Russian language], Filologicheskaya nauka, 5.

BUSLAEV, F.I. (1959), Istoricheskaya grammatika russkogo yazyka [Historical grammar of the Russian language], Moscow, Uchpedgiz.

VINOGRADOV, V.V. (1972), Russkiy yazyk (grammaticheskoe uchenie o slove), 2-je izd. [The Russian language (grammatical study of a word), $2^{\text {nd }}$ edition], Moscow, Vysshaya shkola.

Grammatika russkogo yazyka (1960), [Grammar of the Russian language], vol. 1-2, Moscow.

Grammatika sovremennogo russkogo literaturnogo yazyka (1970), [Grammar of the modern literary Russian language], Moscow.

Kratkaya russkaya grammatika (1989), [Concise Russian grammar], Shvedovoj, N. J. and Lopatina, V.V. (eds.), Moscow.

KuBRYAKOVA, E.S. (1978), Chasti rechi v onomasiologicheskom osveshhenii [Parts of speech in onomasiological interpretation], Moscow, Nauka.

KUBRYAKOVA, E.S. (2004), Yazyk i znanie: Na puti polucheniya znanij o yazyke: Chasti rechi s kognitivnoy tochki zreniya. Rol yazyka $v$ poznanii mira [Language and learning: On the way to getting knowledge of language. The role of language in perception of the world], Ros. akademija nauk, In-t yazykoznaniya, Moscow, Yazyki slavjanskoy kultury.

Lingvisticheskiy entsiklopedicheskiy slovar (1990), [Linguistic encyclopedia], Yartseva, V.N. (ed.), Moscow, Sov. Entsiklopediya.

MASLOV, M. Yu. (1997), Vvedenie v yazykoznanie [Introduction to linguistics], Moscow, Vysshaya shkola.

MESHCHANINOV, I.I. (1978), Chleny predlozheniya i chasti rechi [Members of sentence and parts of speech], Leningrad, Nauka.

MiRIGIN, V.N. (1971), Ocherki po teorii protsessov perekhodnosti v russkom yazyke [Outlines of theory of transitivity in the Russian language], Beltsy.

NIKITIN, M.V. (1997), Kurs lingvisticheskoy semantiki [A course in linguistic semantics], St. Petersburg.

OVSYANIKO-KULIKOVSKIY, D.N. (1902), Sintaksis russkogo yazyka [Syntax of the Russian language], St. Petersburg, Izdanie Zhukovskogo.

PETERSON, M.N. (1925), Russkiy yazyk. Posobie dlya prepodavateley [The Russian language. A teacher's book], Moscow, Leningrad.

POTEBNYA, A.A. (1958), Iz zapisok po russkoy grammatike [Notes on Russian grammar], Moscow, Uchpedgiz.

Russkaya grammatika (1980), [Russian grammar], Moscow, vol. 1.

Russiky yazyk: Entsiklopediya (1997), [The Russian language: Encyclopedia], Karaulov, Yu. N. (ed.), $2^{\text {nd }}$ edition, Moscow, Bolshaya rossiyskaya entsiklopediya, Drofa. 
Sovremenniy russkiy yazyk: Teoriya. Analiz yazykovykh edinits (2001), [The modern Russian language: Theory. Analysis of language units], Ucheb. dlya stud. vyssh. ucheb. zavedeniy: v. 2. Ch. 2: Morfologiya. Sintaksis [Morphology and syntax], Babajtseva, V.V., Nikolina, N.A., Chesnokova, L.D. et al., in Dibrova, I.D. (ed.), Moscow, Izdatelskit tsentr «Akademiya».

SuPRUn, A.E. (1971), Chasti rechi v russkom yazyke [Parts of speech in the Russian language], Moscow, Prosveshhenie.

SHAKHMATOV, A.A. (2001), Sintaksis russkogo jazyka [Russian syntax], Vstu Statya d-ra filol. nauk, prof. E.V. Klobukova; redaktsiya i kommentarii prof. E.S. Istrinoy, $3^{\text {rd }}$ edition, Moscow, Editorial URSS.

SHCHERBA, L.V. (1957), Izbrannye raboty po russkomu yazyku [Selected works on the Russian language], Moscow, Uchpedgiz.

\section{ONLINE REFERENCES}

APRESYAN, Yu. D. (1956), Russkiy sintaksis $v$ nauchnom osveshhenii $v$ kontekste sovremennoy lingvistiki (Scientific treatment of the Russian syntax in the context of modern linguistics), in Peshkovskiy, A.M. Russkiy sintaksis $v$ nauchnom osveshhenii (Scientific treatment of Russian syntax). $7^{\text {th }}$ edition, Moscow, Gosudarstvennoye uchebno-pedagogicheskoye izdatelstvo Ministerstva prosveshheniya RSFSR, ch. IV-XXXIII. (Accessed on 10.10.15). Available at: http://www.twirpx.com/file/726010/.

LOMONOSOV, M.V. (1952), Rossiyskaya grammatika (Russian grammar) in PSS. Tom sedmoy Trudy po filologii (1739-1758) (Full collection of works. V. VII. Works in philology (1739-1758)), Moscow-Leningrad, Izdatelstvo AN SSSR. (Accessed on 10.10.15). Available at: http://az.lib.ru/l/lomonosow m w/text 1765 grammatika oldorfo.shtml.

Obshchiye voprosy teorii chastey rechi. Imya sushhestvitelnoye (General questions of parts of speech theory. Noun). (Accessed on 10.11.15). Available at: http://russiasing.iphil.ru/index.php.

SELIVANOVA, E.A. Kognitiono-funktsionalniy aspekt russkikh chastey rechi (Cognitive and functional aspects of parts of speech in Russian). (Accessed on 10.09.15). Available at: http://refdb.ru/look/1862557.html.

SICHINAVA, D.V. Chasti rechi (Parts of speech). (Accessed on 01.12.15). Available at: http://rusgram.ru/Chasti rechi.

Filipp Fedoroich Fortunatov, (Accessed on 10.10.15) Available at: https://ru.wikipedia.org/wiki/.

FORTUNATOV, F.F. (1956-1957). Izbrannye trudy. Tom I, II. (Selected works. V.I, II), Moscow. (Accessed on 01.10.15). Available at: http://rutracker.org/forum/viewtopic.php?t=1263741. 